Original article

\title{
The role of floral oils in the nestmate recognition system of honey bees (Apis mellifera $\mathrm{L}$.)
}

\author{
Stephen G. Downs*, Francis L.W. RatnieKs, Sarah L. JeFFeries, \\ Helen E. RigBY
}

Department of Animal and Plant Sciences, University of Sheffield, Sheffield S10 2TN, UK

(Received 26 March 1999; revised 11 October 1999; accepted 27 October 1999)

\begin{abstract}
Nestmate recognition is essential for maintaining colony integrity in social insects. To discriminate between nestmates and non-nestmates, social insects use self-produced and environmentally-acquired recognition cues. In honey bees, both types of recognition cues have been implicated. We investigated the effect that floral oils (anethole, citronellal, limonene and linalool) have on the probability of nestmates and non-nestmates being accepted by guard bees at nest entrances. Floral oils did not affect the probability of workers, either nestmates or non-nestmates, being accepted by guards. However, the presence of floral oils did increase the time taken for a guard to reject an introduced bee. These data show that guards are sensitive to floral oils, but use other recognition cues when assessing colony affiliation.
\end{abstract}

honey bee / nestmate recognition / guard bee / environmental cue / floral oil

\section{INTRODUCTION}

The almost universal ability of social insects to discriminate between "friends and enemies', or in more modern terms nestmate and non-nestmates, was recognised over a century ago ([1]; reports made from 1875-1879). The production of the recognition cues that allow this discrimination has since been extensively studied, and the source of nestmate recognition cues in many social insects is now known $[4,8,13,17$, $18,25]$. In the honey bee (Apis mellifera), workers discriminate between nestmates and non-nestmates using both self-produced $[3,6]$ and environmentally acquired cues (see below). Self-produced cues, however, are only important for intercolony recognition

* Correspondence and reprints

E-mail: bop97sgd@sheffield.ac.uk 
when the acquisition of environmental cues is experimentally minimised and they are normally overridden by environmental cues $[8,11]$. Studies have shown that honey bee workers readily acquire recognition cues from food $[12,19,20,21]$, comb wax $[5,7$, $10]$ or the queen $[9,23]$ which are used to discriminate between nestmates and nonnestmates.

Floral oils give flowers their characteristic odours. These odours are transferred onto the forager's cuticle and are gathered along with the nectar and pollen by honey bees during foraging [24]. On returning to the colony, the odours are presumably transferred to other colony members via direct contact with other workers or indirectly via nectar or contact with wax that has absorbed the odours $[2,24]$, although the exact transfer route is unknown. Floral odours are used to pinpoint the exact location of food sources, and bees will mark recruitment targets that lack significant odours (weakly scented flowers or water) with the Nasanov gland [24]. Probably because of their importance in foraging, honey bees can quickly learn floral odours during proboscis-extension conditioning experiments [15].

Previous studies have shown that the probability of a worker being accepted by a sister group can be significantly reduced by keeping one group in a cardboard box containing untreated paraffin wax, and the other on wax infused with anise extract [7]. Similarly, the probability of a 5-day-old worker being accepted by a sister decreased when one of the individuals was exposed to filter paper containing floral oil [2]. These data show that applying floral odours to honey bees affects discrimination and can increase the probability of nestmate (sister) rejection. A recognition system that uses floral odours may, therefore, introduce problems. Under natural conditions, scout bees returning from a new flower species could be refused entry to their colony because they carry novel floral odours. Conversely, a guard might accept workers from other colonies if they have been foraging on the same species as the guard's nestmates. When Bowden et al. [2] repeated their floral oil experiment using foragers and guards collected from a colony and brought into the laboratory, instead of using workers kept in the laboratory as adults, floral oil treatment had no effect on the acceptance of nestmates. To explain this apparent contradiction between laboratory-kept and colonykept workers, they proposed that when workers have been exposed to other cue sources in the nest, as in the second experiment, floral odours are ignored.

The above results clearly demonstrate that acceptance can be greatly affected by experimental methodology. For example, exposure to the nest environment prior to testing greatly affects the importance of floral odours [2]. Prior exposure to the nest, however, might not be the only experimental factor of importance in explaining the difference between the laboratory and field study. If nestmate acceptance is naturally high, it would be difficult to determine whether floral oils are unimportant, as proposed by Bowden et al. [2], or whether the oils themselves reduce aggression (i.e., increase acceptance). In addition, it is possible that guards in their field method may have simply ignored the introduced worker because of the novel surroundings of the container, hence the low rejection probability when workers are collected from a colony and brought to the laboratory [2]. It is also unclear in the Bowden et al. study [2] whether guards always contacted introduced workers.

Given that honey bees are capable of detecting floral odours, the importance of environmental cues in nestmate recognition, and the general relevance of floral odours to the honey bee, further investigation of the role of floral oils in nestmate recognition is an important step in understanding nestmate recognition in Apis mellifera. Our purpose was to test whether floral oils contribute to nestmate recognition by honey 
bee guards in an experimental situation that was close to natural conditions. In particular, actual foraging-age workers were introduced to guards at a nest entrance. Our data show that the presence of floral oils did not affect the probability that guards would accept introduced workers, whether nestmates or non-nestmates. However, the time taken for guards to reject nestmates and nonnestmates did increase when introduced bees were treated with floral oils.

\section{MATERIALS AND METHODS}

The behaviour of guards at the nest entrance towards nestmate and non-nestmate workers that were either untreated or treated with floral odours was observed. It was predicted that floral odours would have no effect on the probability of worker acceptance. This was because our experiment simulated a situation in which workers contacted novel flower types, which is presumably a common occurrence in nature. Rejection of nestmates carrying novel odours would be costly to the colony.

\subsection{Study organism}

Two queenright honey bee (A. mellifera) colonies of mixed European race were studied at an apiary in Sheffield, England, in August 1998. The colonies were housed in standard Langstroth hives of two boxes, volume ca. $90 \mathrm{~L}$, and consisted of a similar population (approximately 20 000-30 000 bees per colony). To facilitate observations of the hive entrance, each hive had a standard 'long' bottom board that extended $5 \mathrm{~cm}$ beyond the hive front.

\subsection{Treating workers with floral odours}

Returning foragers were collected at the entrances of both hives, placed in individual plastic vials and chilled $\left(2{ }^{\circ} \mathrm{C}\right)$. When the chilled bees had become relatively immobile (ca. $5 \mathrm{~min}$ ) they were placed in plastic petri dishes for floral odour treatment. Treatment involved applying $1 \mu \mathrm{L}$ of the test material to the notum of each worker using a micropipette (Finnpipette). The dishes were vented to prevent any buildup of fumes that may have been toxic to the bees. Preliminary tests had established that $1 \mu \mathrm{L}$ of pure floral oil was lethal. As a result, floral oils were diluted in acetone. One-third of the workers were left untreated, one-third were treated with $1 \mu \mathrm{L}$ of a $10 \%$ (v/v) solution, and one-third with $1 \mu \mathrm{L}$ of a $0.1 \%(\mathrm{v} / \mathrm{v})$ solution. Two doses were used so that it was possible to test for any possible effects of floral odour concentration. Floral oils were anethole, citronellal, limonene and linalool (all obtained from Sigma), and were selected as being representative of floral oils produced by many flowers [16]. Acetone was used as a solvent because preliminary tests had shown no significant difference between the acceptance of nestmates treated with $1 \mu \mathrm{L}$ of acetone versus untreated nestmates, and between non-nestmates treated with $1 \mu \mathrm{L}$ of acetone and untreated non-nestmates (untreated nestmates versus acetonetreated nestmates: $60 \%$ versus $65 \%$ acceptance; $\chi^{2}=0.21 ; P>0.05, n=80$; untreated non-nestmates versus acetone-treated nonnestmates: $2.5 \%$ versus $5 \% ; \chi^{2}=0.35$; $P>0.05, n=80)$. In addition, $1 \mu \mathrm{L}$ of acetone did not kill the treated bees or result in any apparent change in their behaviour. Following treatment, the bees were put back into individual vials and chilled $\left(2^{\circ} \mathrm{C}\right)$ ready for introduction within $2 \mathrm{~h}$.

\subsection{Acceptance by guard bees}

Acceptance by guards was measured by observing the interactions between a naturally-occurring guard at the hive entrance and an introduced forager. The foragers were removed from the refrigerator and used for introductions once they had warmed up sufficiently so they could walk but not fly. The 
use of walking, but not flying bees meant that they could be reliably introduced, but were not treated as dead bees and removed by undertakers [26]. When introducing a bee at the hive entrance, the experimenter stood to the side of the hive and was careful not to disturb it by making sudden movements or by jolting the hive. The bees were introduced using forceps to eliminate the possibility of contamination from the experimenter. Following introduction, a guard soon contacted the introduced bee because entrances always had several guards. If the worker was bitten or stung by the guard, this was classed as rejection. When an introduced worker was inspected (antennated and licked) and allowed to enter the hive, or remained at the entrance for five min following inspection and was not rejected, this was classed as acceptance. In addition to acceptance or rejection, the time taken from introduction to rejection (i.e., the time taken for a guard to contact the introduced bee plus the time taken to bite or sting) was recorded, so that we could determine whether floral oils affected rejection times.

A coding system ensured that all introductions were blind, as recommended for recognition studies [14] to avoid any unconscious biasing of results. Two experimenters introduced the bees. The person making the behavioural observations was unaware of both the nest origin (i.e., nestmate or nonnestmate) and treatment (i.e., amount of floral oil) of the introduced worker.
Three hundred and sixty workers were used for each of the four floral oils, i.e., 1440 introductions in total. This consisted, per colony of the following: 30 untreated nestmates; 30 nestmates $+1 \mu \mathrm{L}$ of $10 \%$ solution $\times 4$ oils; 30 nestmates $+1 \mu \mathrm{L}$ of $0.1 \%$ solution $\times 4$ oils; 30 untreated nonnestmates; 30 non-nestmates $+1 \mu \mathrm{L}$ of $10 \%$ solution $\times 4$ oils; and 30 non-nestmates $+1 \mu \mathrm{L}$ of $0.1 \%$ solution $\times 4$ oils. The study was performed during July and August 1998 on days when the bees were foraging.

\section{RESULTS}

\subsection{Effect of floral odours on acceptance probability}

Figure 1 shows that the acceptance of nestmates and non-nestmates was little affected by the concentration of floral oil when compared to controls. Analysis of variance (Tab. I) confirmed that there was no effect of colony or oil. We therefore combined the data across both colonies and floral oils to investigate the effect of treatment (Fig. 1). As expected, there was a highly significant difference between nestmate and non-nestmate acceptance ( $83 \%$ versus $22 \%$ ) $\left(\chi^{2}=180.45 ;\right.$ d.f. $\left.=1 ; P<0.00005 ; n=480\right)$ (Fig. 1). This discrimination is important because under conditions of extremely high availability of nectar, honey bee guards accept all nestmates and non-nestmates (Downs and Ratnieks, unpubl. data). Such

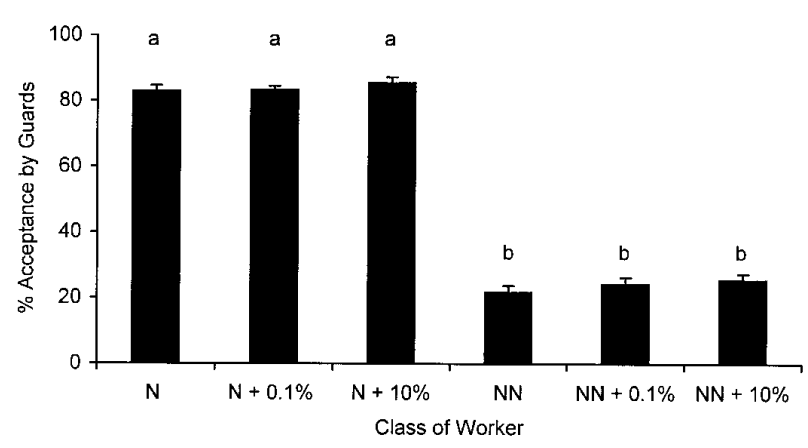

Figure 1. Guard acceptance of different classes of workers at hive entrances. Data is combined from both colonies and the four floral oils used. Key: $\mathrm{N}=$ nestmates; $\mathrm{NN}=$ non-nestmates $;+0.1 \%=$ workers treated with $1 \times \mu \mathrm{L}$ of $0.1 \%$ solution; $+10 \%=$ workers treated with $1 \times \mu \mathrm{L}$ if $10 \%$ solution. Bar $=1$ S.D. Columns with the same letter do not differ significantly (Tukey's pairwise comparison, $P>0.05$ ). 
circumstances would have made it impossible to gather useful data. To investigate the effect of the amount of oil applied $(0$, $0.1 \%, 10 \%)$, nestmates and non-nestmates

Table I. Effect of treatment (without floral oil or with floral oil $\times 2$ dosages), test colony and type of floral oil used for guard acceptance of nestmate and non-nestmate workers at hive entrances. Numbers in parentheses indicate the number of test groups. Analysis of variance shows that only treatment significantly effects guard acceptance.

\begin{tabular}{|c|c|c|c|c|}
\hline $\begin{array}{l}\text { Parameter } \\
\text { tested }\end{array}$ & $F$ & $P$-value & d.f. & $n$ \\
\hline Treatment (6) & 231.32 & $<0.00005$ & 5,42 & 48 \\
\hline Colony (2) & 0.13 & 0.73 & 1,46 & 48 \\
\hline Floral oil (4) & 0.03 & 0.99 & 3,44 & 48 \\
\hline
\end{tabular}

Table II. Effect of treatment (without floral oil or with floral oil $\times 2$ dosages), test colony and type of floral oil used on guard rejection time (s) of nestmate and non-nestmate workers at hive entrances. Numbers in parentheses indicate the number of test groups. Analysis of variance shows that only treatment significantly effects guard rejection time.

\begin{tabular}{lccccc}
\hline $\begin{array}{l}\text { Parameter } \\
\text { tested }\end{array}$ & $F$ & $P$-value & d.f. & $n$ \\
\hline Treatment (6) & 19.76 & $<0.00005$ & 5,663 & 669 \\
Colony & $(2)$ & 0.55 & 0.46 & 1,667 & 669 \\
Floral oil (4) & 1.57 & 0.2 & 3,665 & 669 \\
\hline
\end{tabular}

were analysed separately. The application of floral odours did not affect the probability of either nestmates (ANOVA: $F_{2,22}=$ $0.51 ; P=0.605, n=24$ ) or non-nestmates (ANOVA: $F_{2,22}=0.62 ; P=0.55, n=24$ ) being accepted by a guard (Fig. 1).

\subsection{Effect of floral odours on rejection time}

Figure 2 shows that both nestmates and non-nestmates treated with floral oil took longer to be rejected than untreated workers. As with acceptance probability, the rejection times were not significantly different across both colonies and the four oils (Tab. II), and so the data were combined to determine the effect of treatment (nestmates versus non-nestmates: $0,0.1 \%, 10 \%$ ) (Fig. 2). For the nestmates, the only significant difference was between untreated workers and workers treated with $10 \%$ floral oil (Tab. III). However, both groups of treated non-nestmates (10\% and $0.1 \%)$ took significantly longer to be rejected than untreated non-nestmates (Tab. III). Because fewer nestmates were rejected than nonnestmates $(17 \%$ versus $78 \%)$, the sample size was lower for nestmates than non-nestmates, and consequently the power of the tests for nestmates was lower than for nonnestmates.
Figure 2. Guard rejection time (s) of different classes of workers at hive entrances. Data is combined from both colonies and for the four floral oils. Bar $=1 \mathrm{~S}$. E. Columns with the same letter do not differ significantly (Tukey's pairwise comparison, $P>0.05$ ). Note that the comparisons are only between treated and untreated nestmates, and treated and untreated non-nestmates.

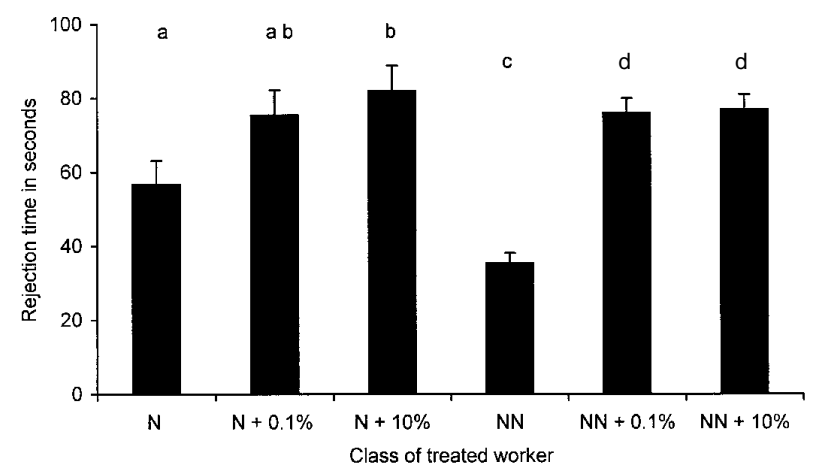


Table III. Analysis of variance and post hoc tests of the rejection times of treated and untreated nestmates and non-nestmates.

\begin{tabular}{lccccc}
\hline Comparison & F & $P$-value & d.f. & $n$ & Tukey's comparison (5\% level) \\
\hline Nestmates & 3.83 & 0.025 & 2,113 & 116 & $\begin{array}{l}\mathrm{N} \neq \mathrm{N}+10 \% \text { solution } \\
(\text { critical value }=3.36)\end{array}$ \\
Non-nestmates & 42.91 & $<0.00005$ & 2,550 & 553 & $\begin{array}{c}\mathrm{NN} \neq \mathrm{NN}+0.1 \% \text { solution; } \\
\mathrm{NN} \neq \mathrm{NN}+10 \% \text { solution } \\
(\text { critical value }=3.31)\end{array}$ \\
\hline
\end{tabular}

\section{DISCUSSION}

Treatment with floral oils did not affect the probability of either nestmates or nonnestmates being rejected by the guards, although floral oils did significantly increase the time taken by a guard to reject both nestmates and non-nestmates. From observing the behaviour of the guards towards treated workers, it appeared that floral oils temporarily confused the guards. In many cases, a guard repeatedly antennated a treated worker before finally rejecting her. Floral oils, therefore, seem to delay rejection without affecting the rejection probability.

Floral odours could in principle be used by guards to determine whether a bee is a returning forager or a robber from another colony, as robber bees will generally not smell of floral cues. But the data from this study show that floral odours are not important in nestmate recognition of honey bees under natural conditions. These data support previous findings which have also shown no effect of floral odours when workers were previously exposed to a nest [2]. Bowden et al. [2] proposed that floral odours are not used because guards would not be able to discriminate between nestmates and non-nestmates which have been foraging on similar flowers. However, foragers that try to enter a different colony are usually 'drifters' that have done so by mistake and are not a threat to the colony, unless they are carrying diseases or parasites which may infect the nest. In such cases, the colony actually benefits from the resources the drifter carries. Honey bees, therefore, have no selective pressure to detect drifting because it does not compromise the survival of a colony. Alternatively, rather than preventing non-nestmate entry, the non-use of floral odours may protect a colony from mistakenly rejecting scout bees that have found a new flower source. This error, however, could be overcome if guards treat all floral odours equally and adopt an acceptall-floral-odours strategy. Both these explanations do not conclusively explain why guards do not use floral odours as recognition cues. The answer may be because foragers can quickly change from foraging on flowers to robbing a vulnerable colony. Floral cues may linger on the forager for a period after it has foraged on a flower. If floral cues did therefore increase guard acceptance, then robbers would be allowed to enter another nest after visiting flowers.

In contrast to our data and other data suggesting that floral cues are not used in nestmate recognition [2], syrup feeding experiments have demonstrated that cues acquired from food (including presumably the same floral odours that were originally in the nectar) can be important for recognition in honey bees. Colonies [12, 19, 20, 21] or sister groups [22] accept introduced workers fed the same flavoured syrup or honey, but attack workers fed differently flavoured syrups or honey. Because acceptance can be altered by feeding workers differently flavoured foods, this would suggest that 
food-derived cues can be important in nestmate recognition. It has been suggested that the recognition effect observed in these experiments was caused by the extraordinarily strong odours that were used [2]. Artificially strong odours, such as treacle [20], may have confused the workers to such an extent that discrimination was impossible. Our study has shown that floral odours can delay rejection, and it may be the case that very strong artificially-applied odours could eliminate recognition completely. However, Saleh-Mghir [22] demonstrated the importance of food-derived cues by feeding workers naturally-occurring honeys. As honey is the natural food of honey bees, these data cannot be explained by unnaturally strong odours.

If odours are applied only to individual workers and not to the whole colony or group, they appear not to affect the probability of acceptance by guards ([2]; and current study). This is probably because the artificially-applied cues only involve a few individuals, and so the colony will have very little contamination. In such cases, it may be better for guards to rely on cues that the majority of nestmates possess rather than using the idiosyncratic cues of each individual worker in a colony. In contrast, when entire groups of workers are exposed to strongly-flavoured food cues, this does effect recognition [22]. It seems likely that this is because treating entire groups with foodborne cues allows all members of the group to acquire the novel cues and consequently a particular cue can be a reliable indicator of colony affiliation. Further study is required to test this hypothesis. One prediction is that acceptance between two groups of bees or colonies gradually increases, or decreases, when they are fed foods with the same, or different, odours over consecutive days. Previous studies that have involved feeding entire groups only began to collect data after 3 days of exposure to food-borne cues [22]. By this stage, however, the groups may have already become saturated or accustomed to the food-odour cues. To better understand the importance of food cues in honey bee recognition, studies are therefore needed that involve the application of food cues to entire groups and the collection of data over several days or more.

Given the significance of floral odours in honey bee foraging, the importance of environmentally-acquired cues in honey bee recognition, and the previous data that demonstrate an effect of food odours, the role of food odours in nestmate recognition remains incompletely known, but is potentially an important element of nestmate recognition in honey bees.

Résumé - Le rôle des huiles florales dans le système de reconnaissance des membres de la colonie chez l'abeille domestique (Apis mellifera L.). La reconnaissance des membres de la colonie est capitale pour le maintien de l'intégrité de la colonie chez les insectes sociaux. Pour discriminer les membres de la colonie des non membres, les insectes sociaux utilisent des signaux de reconnaissance qu'ils produisent eux-mêmes et qu'ils prennent dans l'environnement. Chez l'abeille domestique les deux types de signaux sont impliqués, mais les signaux auto-produits n'ont de l'importance que pour la reconnaissance entre colonies, quand l'acquisition des signaux du milieu est expérimentalement restreinte au minimum, et que les signaux auto-produits sont normalement écrasés par les signaux du milieu issus, pense-t-on, des rayons de cire, de la nourriture et de la reine. Nous avons étudié l'influence qu'ont les huiles florales d'anéthol, de citronellal, de limonène et de linalool sur la probabilité pour une butineuse qui rentre d'être acceptée par une gardienne. On a prélevé à l'entrée de deux colonies des butineuses qui rentraient et on les a soit gardées telles quelles, soit traitées avec $1 \mu \mathrm{l}$ d'une solution d'huile à $10 \%(\mathrm{v} / \mathrm{v})$ ou à $0,1 \%(\mathrm{v} / \mathrm{v})$. Les ouvrières ont été ensuite introduites à l'entrée de leur propre colonie 
(membres de la colonie) ou de l'autre colonie (non membres) et le comportement de la gardienne a été observée. Nos résultats montrent que les huiles florales n'affectent pas la probabilité pour des ouvrières, qu'elles soient membres ou non de la colonie, d'être acceptées par les gardiennes (Fig. 1). Pourtant la présence des huiles florales a bien augmenté le temps pris par une gardienne pour rejeter une abeille introduite (Fig. 2). Ces données montrent que les gardiennes sont sensibles aux huiles florales, mais qu'elles utilisent d'autres signaux de reconnaissance lorsqu'elles vérifient l'appartenance à une colonie. Des études antérieures [12, 19, 20-22] ont montré que les odeurs alimentaires pouvaient influencer l'acceptation des ouvrières et cet article discute les implications possibles du traitement individuel des ouvrières comparé au traitement de groupes entiers par des odeurs alimentaires. Nous suggérons que les odeurs alimentaires peuvent être importantes pour la reconnaissance des membres de la colonie lorsque des colonies entières ont été exposées à l'odeur alimentaire et pensons qu'il faut revoir le rôle des odeurs alimentaires dans la reconnaissance par l'abeille de l'appartenance à une colonie.

reconnaissance membre de la colonie / gardienne / signal du milieu / huile florale

Zusammenfassung - Die Rolle von Blütenölen auf das System der Nestgenossenerkennung von Honigbienen (Apis mellifera L.). Die Erkennung der Nestgenossen ist für die Aufrechterhaltung der Kolonieintegrität sozialer Insekten unabdingbar. Zur Unterscheidung zwischen Nestgenossen und Nicht-Nestgenossen nutzen soziale Insekten selbst produzierte oder aus der Umgebung angenommene Erkennungsmerkmale. Honigbienen verwenden beide Typen von Merkmalen. Selbstproduzierte Merkmale sind für die Erkennung der Koloniezugehörigkeit allerdings nur dann von
Bedeutung, wenn der Erwerb aus der Umgebung angenommener Kennzeichen experimentell minimiert wird. Normalerweise werden sie von den erworbenen Umgebungsmerkmalen überdeckt, es wird angenommen, dass diese vom Wachs der Nahrung und der Königin stammen. Wir untersuchten den Einflu $\beta$ von Blütenölen (Anetol, Zitronellal, Limonen und Linalool) auf die Wahrscheinlichkeit, dass eine rückkehrende Sammlerin von den Wächterbienen akzeptiert wird. An zwei Bienenvölkern wurden rückkehrende Sammlerinnen am Flugloch abgefangen und entweder unbehandelt gelassen oder mit $1 \mu \mathrm{L}$ einer $10 \%$-igen bzw. einer 0,1\%-igen (v/v) Öllösung behandelt. Die Arbeiterinnen wurden dann an dem Eingang des Fluglochs des eigenen (Nestgenossen) oder des anderen Volkes (NichtNestgenossen) freigelassen und das Verhalten der Wächterinnen ihnen gegenüber beobachtet. Unsere Daten zeigen, dass die Wahrscheinlichkeit, mit der die Arbeiterinnen von den Wächterinnen akzeptiert wurden, durch die Blütenöle nicht beeinflusst wurde (Abb. 1). Allerdings verlängerte das Blütenöl die Zeitdauer, bis eine Wächterin eine Arbeiterin zurückwies (Abb. 2). Die Daten belegen, dass die Wächterinnen die Blütenöle zwar wahrnehmen, aber zur Einschätzung der Koloniezugehörigkeit andere Merkmale nutzen. In früheren Untersuchungen war gezeigt worden, dass Nahrungsgerüche die Akzeptanz von Arbeiterinnen beeinflussen können. In diesem Artikel diskutieren wir die Auswirkungen der Behandlung einzelner Arbeiterinnen anstelle ganzer Gruppen mit Nahrungsgerüchen. Wir schlagen vor, dass der Nahrungsgeruch nur dann für die Erkennung von Nestgenossen wichtig ist, wenn die ganze Kolonie dem Futtergeruch ausgesetzt war, und dass die Rolle des Futtergeruchs bei der Erkennung der Koloniezugehörigkeit überdacht werden sollte.

\section{Honigbiene / Nestgenossenerkennung / Wächterbiene / Umgebungshinweis / Blütenöl}




\section{ACKNOWLEDGMENTS}

A BBSRC studentship 97/A1/S/3803 (Stephen Downs) and two Nuffield Science Bursaries (Sarah Jefferies and Helen Rigby) funded this study.

\section{REFERENCES}

[1] Avebury B., Ants, Bees and Wasps, Kegan P., Trench, Trübner \& Co. Ltd., London, UK, 1915.

[2] Bowden R.M., Williamson S., Breed M.D., Floral oils: their effect on nestmate recognition in the honey bee, Apis mellifera, Insectes Soc. 45 (1998) 209-214.

[3] Breed M.D., Nestmate recognition in honey bees, Anim. Behav. 31 (1983) 86-91.

[4] Breed M.D., Bennett B., Kin recognition in highly eusocial insects, in: Fletcher D.J.C., Michener C.D. (Eds.), Kin Recognition in Animals, John Wiley \& Sons, Chichester, 1987, pp. 243-285.

[5] Breed M.D., Stiller T.M., Honey bees, Apis mellifera, nestmate discrimination: hydrocarbon effects and the evolutionary implications of comb choice, Anim. Behav. 43 (1992) 875-883.

[6] Breed M.D., Butler L., Stiller T.M., Kin discrimination by workers in genetically mixed groups, Proc. Natl. Acad. Sci. USA 82 (1985) 3058-3061.

[7] Breed M.D., Williams K.R., Fewell J.H., Comb wax mediates the acquisition of nest-mate recognition cues in honey bees, Proc. Natl. Acad. Sci. USA 85 (1988) 8766-8769.

[8] Breed M.D., Welch C.K., Cruz R., Kin discrimination within honey bee (Apis mellifera) colonies: an analysis of the evidence, Behav. Proc. 33 (1994) 25-40.

[9] Breed M.D., Stiller T.M., Blum M.S., Page R.E Jr., Honey bee nestmate recognition: effects of queen fecal pheromones, J. Chem. Ecol. 18 (1992) 1633-1640.

[10] Breed M.D., Garry M.F., Pearce A.N., Hibbard B.E., Bjostad L.B., Page R.E. Jr., The role of wax comb in honey bee nestmate recognition, Anim. Behav. (1995) 50 489-496.

[11] Downs S.G., Ratnieks F.L.W., Recognition of conspecifics by honey bee guards (Apis mellif- era) uses non-heritable cues acquired in the adult stage, Anim. Behav. 58 (1999) 643-648.

[12] Frisch K. von., The Dance Language and Orientation of Bees, Harvard Univ. Press, Cambridge, MA, USA, 1967.

[13] Gamboa G.J., Kin recognition in social wasps, in Turillazzi S., West-Eberhard M.J. (Eds.), Natural History and Evolution of Paper Wasps, Oxford Univ. Press, Oxford, 1996, pp 161-177.

[14] Gamboa G.J., Reeve H.K, Holmes W.G., Conceptual issues and methodology in kin recognition research - a critical discussion, Ethology 88 (1991) 109-217.

[15] Getz W.M., Smith K.B, Olfactory sensitivity and discrimination of mixtures in the honeybee Apis mellifera, J. Comp. Physiol. A 160 (1987) 239-245.

[16] Harborne J.B., Introduction to ecological biochemistry, 4th ed., Academic Press, London, 1993.

[17] Hölldobler B., Michener C.D., Mechanisms of identification and discrimination in social hymenoptera, in: Markl H. (Ed.), Evolution of Social Behaviour, Chemie Verlag, 1980 , pp. 35-58.

[18] Hölldobler B., Wilson E.O., The Ants, Harvard Univ. Press, Cambridge, MA, 1990.

[19] Renner M., Das Duftorgan der Honigbiene und die physiologische Bedeutung ihres Lockstoffes, Z. Vgl. Physiol. 43 (1960) 411-468.

[20] Ribbands C.R., The scent perception of the honey bee, Proc. R. Soc. Lond. B 143 (1955) 367-379.

[21] Ribbands C.R., Kalmus H, Nixon H.L., New evidence of communication in the honeybee colony, Nature 170 (1952) 438-440.

[22] Saleh-Mghir E., Rôle de la nourriture dans la reconnaissance des congénères chez l'abeille, Apis mellifera L., C.R. Acad. Sci. Paris 315 (1992) 343-346.

[23] Saleh-Mghir E., Darchen R., Le rôle de la reine dans la tolérance entre les ouvrières d'Apis mellifica mellifica, Apidologie 21 (1990) 59-67.

[24] Seeley T.D., The Wisdom of the Hive, Harvard Univ. Press, Cambridge, MA, 1995.

[25] Wilson E.O., The Insect Societies, Harvard Univ Press, Cambridge, MA, 1971.

[26] Visscher P.K., The honey bee way of death: necrophoric behaviour in Apis mellifera colonies, Anim. Behav. 31 (1983) 1070-1076. 